\title{
EYL in Indonesia: Implementations, Problems, and Challenges
}

\author{
Musiman ${ }^{*}$, Anam Sutopo ${ }^{2}$, R.Muhammad Ali ${ }^{3}$, Madya Giri Aditama ${ }^{4}$, \\ Alivermana Wiguna ${ }^{5}$ Ahmad Syafiq ${ }^{1}$ \\ ${ }^{I}$ Faculty of Teacher Training and Education, Universitas Muhammadiyah Lampung \\ ${ }^{2}$ Faculty of Teacher Training and Education, Universitas Muhammadiyah Surakarta \\ ${ }^{3}$ Faculty of Teacher Training and Education, Universitas Ahmad Dahlan, Yogyakarta \\ ${ }^{4}$ School of Teacher Training and Education, STKIP Muhammadiyah Batang \\ ${ }^{5}$ School of Teacher Training and Education, STKIP Muhammadiyah Sampit \\ *Corresponding author, e-mail: mus.um.lampung @gmail.com
}

\begin{abstract}
English is becoming more and more important language in th $21^{\text {st }}$ century. To respond this condition, some countries start introducing English to their school students earlier. In the newest Curriculum 2013, Indonesian government changes the status of English in elementary school to be an extracurricular activity which was stated as a local content in the previous curriculum. This policy becomes a great concern for some teachers and educators in Indonesia. To address this problem, the writer try to analyze it by proposing three problems; How is the implementation of teaching English as a foreign language in Elementary schools, What are the problems in teaching English in Elementary schools, and What are the challenges of teaching English in Elementary schools. Data were collected from previous research findings, and find out that many elementary schools still teach English with some problem such as unqualified teachers and unsatisfactory learning outcome. Thus, it is challenge for all the stake holders, especially government and higher education institutions.
\end{abstract} Keywords: English for Young Learner, elementary school, English as Foreign Language, curriculum

\section{INTRODUCTION}

One of the noticeable changes in the $21^{\text {st }}$ century is the increase of interaction among nations all over the world. There seems to be no border between one nation to the other nation, the world becomes a global village (Mappiasse \& Johari, 2014)[1]. The advancement of communication technology enables people to get informed almost about any event in any corner of the world. As a result, English is becoming more and more important language for every person. Some people claim that English language has now become world's language for research, publication, business and commerce, politics and other areas of life (Toker, 1999 in Mappiasse \& Johari, 2014)[1].

Furthermore, Mappiasse \& Johari 2014) [1] cited Lauder (2008) who stated that English is being used for following technological and scientific improvements and also for better job opportunities. Therefore many countries teach English to their school students early. Gradol in Iuliana Lungu (2015)[2] states that English is increasingly seen a generic skill, leading governments and educational policy developers to lower the starting age with the aim of building strong English proficiency levels for an English-speaking workforce.

Whether we like it or not, we can not deny English in our daily activities nowadays. We need to interact with all people around the globe in order to fulfil our daily need. Manara (2014) in Azmy (2020)[3] states that no nation can withdraw from the globalized used of English that notably change human's interaction and relationship to communicate nowadays.

Indonesia as part of the world of course gets the impact of this changes. Alwasilah, 1997 in Mappiasse 2014 [1] states that English is recognized as the most significant 
foreign language in Indonesia since 1980s and this has witnessed a tremendous growth since the early 1990s.

In Indonesia, English is taught as a Foreign Language to the school students. Before 1993, English was taught as a compulsory subject in Junior and Senior High Schools. After the Decree of the Ministry of Education and Culture No. 060/U/1993, 25 February 1993, besides as a compulsory subject in High Schools, English was listed as one of the local subjects for Elementary Schools. In the current running known as curriculum 2013, English is no longer listed as one of the local subjects in Elementary School. However, English may be taught in elementary school as an extracurricular activity.

Diem (2014) [4] states that the current issue of significant concern among literacy educators is whether English as a foreign language (EFL) literacy needs to be maintained as a local content or a compulsory subject in Indonesian primary schools. In fact, the learning of English literacy has become a trend in many major cities in Indonesia, including in Palembang, South Sumatra.

Eventhough in the 2013 Curriculum English is only an extracurricular activity, it is a fact that some elementary schools in Indonesia still teach English to their students (Habibi \& Sofwan, 2015) [5]. Parents want their children learn English earlier to prepare their future. Some people think that government's policy related to English subject in Elementary school in Indonesia is a backwardness. Therefore, it seems that the practice of teaching English to Elementary schools students does not really change before and after the Curriculum 2013 was issued.

If the reason of changing English subject from a local content in the previous curriculum into an extracurricular activity in the new curriculum because the result of teaching English in Elementary school is not satisfactory, it is not a solution. Evaluating the implementation, identifying the problems and challenges is worth to do.

Thus, in this article, the writer wants to collect some information from many references and previous researches concerning to the implementations, problems, and challenges about teaching English in Indonesia, especially in the Elementary schools. Thus, the writer formulates three problems in this article as; 1) How is the implementation of teaching English as a foreign language in Elementary schools, 2) What are the problems in teaching English in Elementary schools, and 3) What are the challenges of teaching English in Elementary schools

\section{METHOD}

This article is a descriptive library study, in which the writer attempts to describe systematically a situation, problem, phenomenon or provide information about the condition by examining some existed references of relevant topics (Arikunto 2010, Kumar 2011, Nazir 2017) [6]-[8]. Related to a hypothesis, this study is an exploratory, in which it is not aimed at testing a hypothesis (Kothari, 2004) [9].

This article is considered as a conceptual paper examining the existed literature reviews, in which some relevant topic from academic works were critically chosen and reviewed to find the information needed (Azmy, 2020) [3]. The data analysis is conducted utilising secondary data analysis in which the data are gathered from previous literature from other articles. In order to analyse the data, the current work assembled plenty of resources such as from reputable articles, books, academic journals and others in the area of elementary English education both in Indonesian context and international context are collected and analyzed to answer the problems and formulate some possible recommendations and suggestions for future practice.

Hopefully, from this study the writer can present more comprehensive information about the topic.

\subsection{The Implementation of TEFL to Young Learners in Indonesia and Its Result}

Many previous studies about the implementation of TEFL to elementary schools in Indonesia have been done. Thus, in this section, the writer will present how it is implemented and what the outcome is.

\section{a. The Implementation}

English for Young Learners (EYL) has become popular throughout Indonesia. Many elementary schools all over Indonesia teach English to their students, some schools start teaching it from the $1^{\text {st }}$ grade, some others start from the $4^{\text {th }}$ grade. In the urban areas (around the province), most elementary schools teach English start from their $1^{\text {st }}$ grade students, especially the private (non-government) schools. Even many kindergartens in urban areas introduce English to their students.

Diem (2014) [4] states that in fact, the learning of English literacy has become a trend in many major cities in Indonesia, including in Palembang, South Sumatra. Similarly, Sutarsyah (2017) [10] also states that recently in Lampung, English is taught in many elementary schools and almost all favorite private elementary schools teach English as one of the compulsory subjects. Khafidhoh et all (2019) [11] state that English is one of the pre-eminent subjects in Muhammadiyah elementary schools. 
Yusfardiah (2010) in Diem (2014) [4] reported that all $(100 \%)$ of the 42 schools which were randomly and hierarchically selected from the 348 elementary schools in the city of Palembang, South Sumatra, have been offering English as a local content subject and some have even started from the first grade. Admittedly, the offer of English to be given as a local content in primary schools is basically due to the need of the stakeholders, especially parents of the students, who want English to be taught early in the school for anticipating the future competitiveness of their children in the global era.

Similar to the urban areas, many elementary schools and kindergarten located around the districts also teach English to their students. In some of these elementary schools, English is taught from the $1^{\text {st }}$ graders, while in some others it is taught from the $4^{\text {th }}$ graders. Habibi and Sofwan (2015) [5] surveyed the elementary schools in Jambi and revealed that some primary schools across the country still provide English as a lesson taught.

In Rural areas (sub-district), many elementary schools also teach English to their students. In most of these schools, English is taught to the $4^{\text {th }}, 5^{\text {th }}$, and $6^{\text {th }}$ graders. Some kindergartens also introduce English to their students. Diem (2014) [4] cited (Cameron, 2001; Harley, Howard, \& Hart, 1995) who state that most people assume that literacy learning at those ages has many benefits. There are many previous researches about EYL already done. To mention some are; Yusuf (2007), Sikki, Rahman, Hamra \& Noni (2013), Alwasilah (2004). Those researches indicate that many elementary schools through out Indonesia teach English to their students.

\section{b. The Result of EYL}

Many previous studies about EYL in Indonesia have been done. Most of the researches were done in the local area and were not intended to draw a generalization for Indonesia. However, if the result shows similar things, we have enough proof to take a conclusion.

As it is stated previously that here has been no standard in how the English for Young Learners should be handled, therefore the result cannot be expected to help improving the quality of the English competence in the higher educational levels (Supriyanti N. (2012) [12]

Diem, 2011 in Diem (2014)[4] studied the implementation of EYL in Palembang and reported that the literacy skill achieved by the students in Palembang has still not been satisfactory. Furthermore, she states that the poor literacy skill as revealed by various studies, at the national, regional, or international level, indicate that the literacy achievement of Indonesian people cannot be proud of, compared with those of other countries and therefore, needs to be improved.
Khafidhoh et all (2019) [11] studied the implementation of teaching English in SD Muhammadiyah Miliran, Yogjakarta found out that the students' mastery of vocabulary is still low and their English speaking skill needs to improve. Similarly, Maili (2018) [13] also found that the outcome of learning English in Elementary school is not satisfactory yet.

Azmy (2020) [3] found out that teaching English at a young age is not practically efficient in Indonesia due to lack competence of teachers, unrelated syllabus and uninteresting teaching methods. Furthermore, he cited (Hawanti, 2014; Lestari, 2003; Rachmajanti, 2008) who state that the efficiency of learning English for primary students seems far from satisfaction in Indonesia due to the lack of competent English teachers. In brief, it can be stated that the effectiveness of learning English in Indonesia is still far from satisfying achievement.

In addition, the aptitude to communicate in English is a very difficult mission in Indonesia because of the emphasis on the national language. The fear of making mistakes has affected the rate of personal expression so much that not all of the students in an EFL (English as Foreign Language) speaking class have the courage to speak. Many of the students feel anxious in a speaking class (Padmadewi, 1998); and some are likely to keep silent to avoid making mistakes (Tutyandari, 2005 as reported by Mappiasse \& Johari (2014) [1]

\subsection{Problems in Teaching English in Elementary Schools}

Many researches have been done about the problems of teaching English in Indonesia. The findings about the problems can be classified as problems related to; government policy, teachers' qualification, curriculum, and facilities.

\section{a. Government Policy}

Indonesia Government recently changed/revised its curriculum into the newly known as Curriculum 2013. In this curriculum, English is not listed either as a national intra curricular subject or as a local content subject in the elementary school. According to this new curriculum, English might be taught in elementary school as an extracurricular activity. In the previous curriculum, known as KTSP/Curriculum 1994, English was listed as one of the local content subject.

Some people claims this policy as the inconsistency of Indonesia Ministry of education policy of whether important or not to include English as either compulsory or local content object in primary school curriculum. In 
addition, this has recently become the real issue among educational stakeholders across the country (Habibi and Sofwan, 2015) [5].

\section{b. Teachers' Qualification}

Many researches have been done about teaching English in Elementary Schools in many different places throughout Indonesia. Although some of these researches were done separately and not intended to take a generalization, but most of them revealed similar condition. Some research showed limited numbers about EYL teachers' qualification at Elementary Schools in Indonesia (Husein, 2014) [14].

Furthermore, Husein (2014) [14] also cited some studies with similar findings. Karani (2006) found that in Palangkaraya, only $30 \%$ of the EYL teachers were very proficient and proficient in English. Especialy in more remote areas in Indonesia, Grassick (2007) revealed that there was a shortage of skilled ES English teachers. While Gunawan and Suharno (2008) in Bandung, found teacher's lack of understanding concerning EYL teaching and learning principles. In Palangkaraya, Karani (2006) discovered that only $30 \%$ of the EYL teachers were very proficient and proficient in English, and only $10 \%$ performed joyful learning using songs, stories, games, and media.

Then, a three-year research conducted by Suyanto et al. (Suyanto, Sulistyo \& Widayati, 2001; Suyanto, Rachmajanti \& Lestari, 2002, 2003) has shown that most EYL teachers teaching in the primary schools are not qualified to teach English to young learners because of their education background. Grassick (2007) states that they teach children based on their previous learning experience dominated by grammar translation method, emphasis on grammatical accuracy, low student involvement, teacher-centered and little meaningful communication (Hussein, 2014) [14]

In short, Husein 2014 concludes that that there were limited numbers of qualified English teachers at Elementary schools in Indonesia

Similarly, Habibi \& Sofwan (2015)[5] studied the profile and proficiency of English Teachers for Young Learners in Jambi. Fifteen teachers English teachers of the $4^{\text {th }}-6^{\text {th }}$ grade of elementary schools were purposefully involved. The result shows that most of the teachers are not qualified in term of English proficiency and they lack involvements of TEFL training.

In addition, they also cited some previous researches with similar findings. Yusuf (2007) who claims that there are limited numbers of Indonesian TEYL teachers who have good English and sufficient knowledge on how teaching English to young learners. Sikki, Rahman, Hamra \& Noni (2013) state that the result of test on professional competency shows that more than $50 \%$ of teachers are in the category of poor and fair. The result of test on pedagogic competence shows that $181(90.5 \%)$ teachers are in the category of poor and fair. Alwasilah (2004) reported that teachers who teach English to young learners in Indonesia are lack of the competence. Furthermore, she prescribes that only few teachers comprehend the principles of teaching English to young learners.

Another study done by Indah (2011)[15] found out that most of EYL teachers teaching in the primary schools in Malang are not qualified because only $46 \%$ had English education background. The class activities do not facilitate real English communication as teachers mostly $(82.1 \%)$ only relied on the English textbooks which quality is also questionable. Furthermore, she reported that the teachers are non-native teachers who still have problems with fluency and vocabulary skill. Therefore, before developing their students' vocabulary, they need to emphasize on vocabulary by autonomous learning (Kwedju, 1999). As a result, Even in English class, communicating in English is not promoted by the class activities. Students listen, repeat and try to memorize words but they don't get enough exposure or actual language practice.

Still in Malang, Setianingsih (2019) [16] cited a study by (Suyanto \& Sulistyo 2001) who reported about $80 \%$ of EYL teachers did not have English education background, meanwhile Suyanto and Sulistyo in (Husein, 2014) [14] found that only $46 \%$ of EYL teachers have English education background at Elementary school in Malang and Malang district.

Sutarsyah (2017)[10] states that most English teachers at elementary schools in Lampung are the graduates of English Education of Lampung University which are prepared to be English teachers at Junior and Senior High School. They teach English to young learners the same way as teaching English to Junior and senior High school students. In some elementary schools, even English is taught by the available teachers (who might not majoring in English education).

Similar finding is reported by Indah (2011) [15] who states that most of EYL teachers teaching in the primary schools are not qualified because only $46 \%$ had English education background. The class activities do not facilitate real English communication as teachers mostly $(82.1 \%)$ only relied on the English textbooks which quality is also questionable.

Besides their education background which does not match to the job, Perwitasari et all (2012 [17] states that there are still many English teachers of elementary school who are very reluctant in creating interesting technique for teaching English to the students. They used teachercentered approach and a monotonous technique (Pertiwi 
et all, 2020) [18]. As a result, the students are less motivated in studying English, they do not pay attention to the material and many of them are preoccupied with themselves, chatting with other friends.

Azmy (2020) [3] concludes that there are two fundamental issues identified by Hawanti (2014) related to the capability of English teachers in elementary school, which are first most of the teachers have no background of English teaching skills, and secondly, those who have the qualifications are not prepared to teach in primary level.

In addition to teachers' qualification, Zein (2017) in Setianingsih 2019 [16] states that there are only 62.883 English teachers supporting 177.985 elementary schools (that teach English). Thus, the recent study yield the optimal implementation cannot be achieved, due to the shortage of proficient English teachers and nothingness of policy decree.

\section{c. Curriculum of Elementary School}

Another problem about teaching English at elementary school in Indonesia as stated previously, is the curriculum. So far, the education policy of Indonesia government has not really support the teaching of English to Young Learners. English is stated as a foreign language and it is included as a compulsory subject only in high schools and university, not in elementary school.

During the 1994 Curriculum, English was listed as one of the local content subjects for the school to choose. It means, during this period, elementary schools might teach English to their students as a local content. There is no mandatory of elementary school to teach English to their students. Moreover, being a local content, the government lets the schools and local government to design their own curriculum and syllabus for English education. The problem is, not all elementary schools and local government are ready and capable to design it due to their human resource about EYL. In addition, if any school is ready and capable of designing it, there will be no standard or model about EYL in Indonesia.

Sutarsyah (2017) [10] states that at present, there is no complete written English Curriculum for Elementary school. The only available document is short description about English subject as one of the local content.

Mappiasse \& Johari (2014) Some of the identified problems of existing curriculum include the allocation of inadequate time for English lesson, lack of resources and instructional materials, lack of motivation by the stakeholders and open display of disgust for the language by students. Teachers are also faced with many problems in the course of their duties in teaching English as foreign language especially with overcrowded classrooms and inadequate continuous development programs.

In the current running 2013 Curriculum, English is not listed as a local content any longer, but the elementary school still might teach English as an extracurricular activity. The changing of the English status in the curriculum from a local content into an extracurricular activity influences much its implementation. Even some people misinterpret the decree, as if English is abolished from the Curriculum of elementary school. However, many elementary schools still teach English to their students since society and parents want to their children to learn English.

Having such condition described above, it is very probable that the atmosphere of learning English in elementary schools will not be effective. More over, the school support as well as the local government support may not be maximum either.

\section{d. School support \& facilities}

Learning process will run effectively if it is supported by all related parties, especially the school and school facilities, otherwise it will be quite difficult for teachers to have maximum result. For example, an effective classroom needs some teaching media and facilities that might be hard for teachers to afford. Besides, ideal teacher should be active in professional development that must be supported also by the school. If the status of English is only a local content or an extracurricular activity, the school might not give a high priority to support because there are a lot of things that the school have to afford.

Many previous researches have tried to have a look at the school support and facilities to support the implementation of EYL in Indonesia. Indah (2017) [19] cited Suyanto \& Rachmajanti, 2008 who reported that the available materials used in primary schools were produced locally and have not been evaluated by the national textbook reviewers. Furthermore, she explains that many of the obstacles are beyond teachers' capability to surmount, such as limited number of hours, class size, insufficient good supplementary materials, etc.

In rural areas, the condition even worse, as Munifatullah 2014 [20] who found out that English teachers in rural and urban area were isolated from source of information, support from school and other related parties, and experienced misperception on their needs to their classroom practice. However, their plan to be professional remained strong. The challenge of 'isolation' led novice into lack of support from school as structure and community of practice. The challenge of classroom 
practice had caused confusion or misperception on how to handle classroom practice.

Besides school support and facilities, teacher professional development is also a problem.

Hartati 2014 [21] reported that teacher empowerment hasn't run according to the function of management and the empowerment elements -- conducive situation, motivation, potential, opportunity, protection, and awareness. The empowerment steps -- enabling, facilitating, consulting, collaborating, mentoring, and supporting haven't been followed well, so it hasn't been able to improve the teachers' competencies optimally.

\subsection{Challenges of Teaching English in Elementary Schools}

In this part, the writer will present the suggestion/recommendations made by the previous researchers and the implied challenges of English for Young Learners in Indonesia.

\section{a. Recommendation}

Due to the importance of English, so many researches done previously done in the local area recommend that English is taught as a compulsory subject in elementary schools in Indonesia (Maili 2018; Khafidhoh et all 2019; Perwitasari et all 2012; Mappiasse \& Johari 2014; Setianingsih 2019; Azmy 2020) [1], [3], [4], [11], [16], [17]

Of course the inclusion of English as one of the compulsory subject in elementary school, of course, is not enough. It must be followed by other actions such as preparing the detailed curriculum and syllabus of EYL, providing professional teachers, and also the supporting facilities (Sutarsyah, 2017) [10].

Mappiasse \& Johari 2014 [1] recommend that there should be constant re training of teachers and students in order to level up with international standard and make business transactions and dealing easy for Indonesians. Improving on the English language as part of the curriculum will also give an additional advantage to the graduates to be able to get job opportunities at international levels. It is therefore to very paramount to evaluate the English and a foreign language as part of the curriculum in Indonesia.

Realizing the importance of English and to prepare their students to be more competitive, Azmy (2020) says that some countries, including East and Southeast Asian nations (ASEAN) introduce English to their primary school students. Furthermore, he also cited Nguyen (2011), Zhetpisbayeva \& Shelestova (2016), and Darmi
\& Albion (2013) who say that Vietnam, Kazakhstan, and Malaysian governments put English in their Curriculum for primary schools.

Similarly, to improve EYL, Mattavarat 2017[22] suggests to raise the admission standards for teacher preparation program at universities, to implement a preparation program for primary school teachers with high standards, to raise the licensing standards, and to improve management of organizations in preparing highquality primary school teachers.

In short, most of the previous researches findings recommend that English is taught to the elementary school students in Indonesia with some improvements. In addition, we have to put more attention to the primary education because it is the foundation for the restoration of a great nation (Mattavarat et all 2017) [22]. Among the improvements recommended, the most important aspect is the availability of professional English teachers for elementary school. As Habibi \& Sofwan, 2015 [5] say that the teacher's quality of young learners can be said as the most important factor not only to bring success of the teaching process but also to promote students achievement.

It is a challenge for all stake holders in Indonesia to prepare the professional English teachers for elementary school. All parties must have the same perception and work hand in hand doing their respective roles. Mattavarat 2017 [22] says that government's policy is an important tool to make educational progress in the desired direction by guiding teacher preparation. University has to design its curriculum to respond the policy, as Istoroyekti, 2016 [23] states that small changes started from university can be the stepping stone towards quality education.

\section{b. Challenges}

Based on the discussion above, there are three main challenges to improve the quality of EYL in Indoneisa, the government policy, university curriculum, and professional development system for teachers. First, the government should declare that English is a compulsory subject for elementary school students. Declaring English as a compulsory subject for elementary school, of course the government has to design the curriculum, syllabus, as well as the material of English for elementary schools in Indonesia. By doing so, there will be very clear and precise goals of learning English in elementary schools. In addition, there will also be a standardized material to use for the teachers.

Declaring English as compulsory subject as well as designing the curriculum, however, is not enough because policy and curriculum can not do anything. 
Lengkanawati (2005) [24] states that we are fully aware that no matter how good and well developed a curriculum is if it is implemented by under qualified teachers it would not result in fruitful outcome. Furthermore, she explains that curriculum revision would not be effective if it is not accompanied by other necessary efforts to improve education as a whole. The other most necessary effort in this case is the qualified English teachers for elementary schools. Setianingsih 2019 [16] says that the teacher as the central of teaching and learning in the classroom plays important role in the program.

Second, talking about the qualified English teachers, it is a challenge mostly for the higher education institutions/universities. Especially about the professional English teachers, Alhasani (2016) [25] says since building up and strengthening human capital in English is predominantly the responsibility of higher education institutions, English Education Departments have to design their curricula, in this case to ensure they can produce professional English teachers for elementary school.

Unfortunately, Supriyanti (2012) [12] states that so far is that there has been no formal pre service trainings for English teachers in elementary schools in Indonesia. Furthermore, she explains that some universities include an insignificant numbers of credits of semester for courses the content of which might cover a little bit introduction to the teaching of English to young learners. This is obviously inadequate for providing appropriate trainings for teaching English to children. No teacher education institutions have seen the need to provide English teachers for elementary schools.

Husein (2014) [14] says that related to teacher preparation at education institutions, since 1994 some of the English Departments, such as IKIP Malang (now State University of Malang), have offered EYL course as an elective subject, not a compulsory one yet. Supriyanti (2012) [12] says that in 1994 when English was firstly introduced to the elementary schools, the English Eduaction Department of Yogyakarta State University developed the optional packages of English for children consisting 16 credits in its curriculum, though it was already realized that there were obstacles. Furthermore, Supriyanti (2014) [26] claims that the optional package of courses has turned out the teacher-students into good teachers of young learners who can provide appropriate instruction to the age group from our experience.

Looking at the real condition above and learning from the experience of Yogyakarta State University, it is a challenge and also an opportunity for English education departments in the higher education institution to design a curriculum that really prepares English teachers for elementary school not only providing an optional package.

Third, there must be a good system of professional development for teachers. In order to improve their professionalism and to keep them being up to date to the development of science and technology, a good professional development system needs to be designed. Mahmoudi \& Ozkan. 2015 [27] found out that experienced and novice teachers benefited from professional development activities. In addition, Celik et all 2013 [28] report that teachers considered professional development to be important. Sulistyorini. 2014 [29] also claims that professional development is a must and urgently required for the teachers. Last, Irmawati 2014 [30] says that some models of PD for EFL teachers are proven effectives to improve EFL teachers professionalism.

\section{CONCLUSION}

Based on the discussion above, there are three main challenges to improve the quality of EYL in Indoneisa, the government policy, university curriculum, and professional development system for teachers. First, the government should declare that English is a compulsory subject for elementary school students. Second, talking about the qualified English teachers, it is a challenge mostly for the higher education institutions/universities. Third, there must be a good system of professional development for teachers.

\section{ACKNOWLEDGMENT}

Thank you very much for the Association of Educational Institutes of Muhammadiyah Universities (ALPTK-PTM) who has already supported this work. Very special thank goes to Mr. Prof. Dr. Harun Joko Prayitno as the chairman of ALPTK-PTM and the team who have given their hands from the preparation of the presentation to the publication of this article.

\section{REFERENCES}

[1] S. S. Mappiasse, A. Johari, and B. Sihes, "Evaluation of English as a Foreign Language and Its Curriculum in Indonesia : A Review," English Lang. Teach., vol. 7, no. 10, pp. 113122, 2014, doi: 10.5539/elt.v7n10p113.

[2] I. LUNGU, "A New Model of Professionalization of Teachers in Pre-school and Primary School Education," Procedia Soc. Behav. Sci., vol. 180, pp. 632-638, 2015.

[3] K. Azmy, "Examining the issue of abolishing English Tuition in Primary School in Indonesia," Lang. Res. Soc. J., vol. 1, no. 1, pp. 47-57, 2020. 
[4] C. D. Diem, "English Literacy Education in Primary Schools: Opportunities and Challenges in Global Competitiveness," in English Language Curriculum Development: Implication for Innovation in Language Policy and Planning, Pedagogical Practices, and Teacher Professional Development, 2014, pp. 1241-1244.

[5] A. Habibi and M. Sofwan, "Teachers of English for Young Learners : An Analysis on Their English Proficiency and Profile," 2015.

[6] S. Arikunto, Prosedur Penelitian Suatu Pedekatan Praktik, Edisi Revi. Jakarta: Rineka Cipta, 2010.

[7] R. Kumar, Research Methodology: A Step-byStep Guide for Beginners, 3rd Editio. New Delhi: Sage, 2011.

[8] M. Nazir, Metode Penelitian, Cet. Keseb. Bogor: Ghalia Indonesia, 2017.

[9] C. R. Kothari, Research Methodology, Methods and Techniques, Second Rev. New Delhi: New Age International Publishers, 2004.

[10] C. Sutarsyah, "Pembelajaran Bahasa Inggris sebagai Muatan Lokal pada Sekolah Dasar di Propinsi Lampung," AKSARA J. Bhs. dan Sastra, vol. 18, no. 1, pp. 35-43, 2017.

[11] R. N. Hidayati, R. M. Ali, and Khafidhoh, "English Mentoring Program di SD Muhammadiyah Miliran, Yogyakarta," in Seminra nasional Hasil Pengabdian kepada Masyarakat Universitas Ahmad Dahlan, 2019, no. September, pp. 755-760.

[12] N. Supriyanti, "Challenges in Providing Trainings for English Teachers of Elementary Schools," J. Educ. Learn., vol. 6, no. 3, pp. 161-166, 2012.

[13] S. N. Maili, "Bahasa Inggris pada Sekolah Dasar: Mengapa Perlu dan Mengapa dipersoalkan," J. Pendidik. Unsika, vol. 6, no. 1, pp. 23-28, 2018, [Online]. Available: https://journal.unsika.ac.id/index.php/judika/a rticle/view/1203.

[14] R. Husein, "A Profile of Exemplary Teachers of English for Young Learners at The Elementary School," J. Pendidik. Hum., vol. 2, no. 4, pp. 311-321, 2014.

[15] R. N. Indah, "TESOLin Indonesia: Between Challanges and Prospects," State University of Malang, 2011.

[16] I. Setianingsih, "The Strategy to Accomodate the Student's English Needs in the 2013 Curriculum at MIN 1 Malang," University of Muhammadiyah Malang, 2019.

[17] I. A. Perwitasari, A. Sutopo, and D. Haryanti, “Improving Students' Vocabulary Using
Cartoon for the Fourth Students of SDN Ngemplak 01 Kartasuran in 2011/2012 Academic Year," Muhammadiyah University of Surakarta, 2012.

[18] R. S. Pertiwi, I. Salabiyati, D. Damara, and B. W. Pratolo, "The Teacher's Perspectives About Challenges of Teaching English for Young Learners: A Case Study at English Course for Young Learners," Adv. Soc. Sci. Educ. Humanit. Res., vol. 397, no. Icliqe 2019, pp. 65-74, 2020, doi: 10.2991/assehr.k.200129.009.

[19] R. N. Indah, "Policy on Foreign Language Education: Rethinking the First Thing First." Makasar, 2017.

[20] F. Munifatullah, "Challenges Encountered by Novice Teachers to develop their Professionalism," in English Language Curriculum Development: Implication for Innovation in Language Policy and Planning, Pedagogical Practices, and Teacher Professional Development, 2014, pp. 12781281.

[21] A. Hartati, "Teacher Empowerment Through MGMP," in English Language Curriculum Development: Implication for Innovation in Language Policy and Planning, Pedagogical Practices, and Teacher Professional Development, 2014, pp. 1231-1235.

[22] S. Mattavarat, P. Viseshisiri, and $P$. Siribanpitak, "Proposed policy for preparation of high-quality primary school teachers in Thailand," Kasetsart J. Soc. Sci., vol. 38, pp. 105-110, 2017.

[23] Y. M. Istoroyekti, "Issues Challenging Universities: A case of Tanzanian Higher Education," Ahmad Dahlan J. English Stud., vol. 3, no. 1, pp. 51-62, 2016.

[24] N. S. Lengkanawati, "EFL Teachers â€ $€^{\mathrm{TM}}$ competence in the Context of Engrish Curriculum 2004: Implications for EFL Teacher Education," TEFLIN J., vol. XVI, no. $1,2005$.

[25] M. D. Alhasani and F. Alhasani, "An Issue of Pedagogical Concern_ Why does it Take So Long to Albanian Students to Develop English Communicative Fluency," Procedia Soc. Behav. Sci., vol. 232, pp. 514-519, 2016.

[26] N. Supriyanti, "Equipping English Education Graduates with the Core Competence of English Teacher FYL throgh an Optional Package Course," in English Language Curriculum Development: Implication for Innovation in Language Policy and Planning, Pedagogical Practices, and Teacher Professional Development, 2014, pp. 1319- 
1321

[27] F. Mahmoudi and Y. Ozkan, "Exploring Experienced and Novice Teachers' Perceptions about Professional Development Activities," Procedia Soc. Behav. Sci., vol. 199, pp. 57-64, 2015.

[28] S. Celik, S. B. Cepni, and H. Ilyas, "The Need for Ongoing Professional Development Perspectives of Turkish University-Level EFL Instructors," Procedia Soc. Behav. Sci., vol. 70, pp. 1860-1871, 2013.

[29] N. E. Sulistyorini, "Teachers' professional Empowerment Through Team Teaching," in
English Language Curriculum Development: Implication for Innovation in Language Policy and Planning, Pedagogical Practices, and Teacher Professional Development, 2014, pp. 1315-1318.

[30] D. K. Irmawati, "Models of EFL Teachers' Professional Development," in English Language Curriculum Development: Implication for Innovation in Language Policy and Planning, Pedagogical Practices, and Teacher Professional Development, 2014, pp. 1254-1257. 